\title{
Production and Measurement of \\ Minor Actinides in the \\ Commercial Fuel Cycle
}

\author{
Compiled by \\ William D. Stanbro
}

\section{DISCLAIMER}

This report was prepared as an account of work sponsored by an agency of the United States Government. Neither the United States Government nor any agency thereof, nor any of their emplcyees, makes any warranty, express or implied, or assumes any legal liability or responsibility for the accuracy, completeness, or usefulness of any information, apparatus, product, or process disclosed, or represents that its use would not infringe privately owned rights. Reference herein to any specific commercial product, process, or service by trade name, trademark, manufacturer, or otherwise does not necessarily constitute or imply its endorsement, recommendation, or favoring by the United States Government or any agency thereof. The views and opinions of authors expressed herein do not necessarily state or reflect those of the United States Government or any agency thereof. 


\title{
PRODUCTION AND MEASUREMENT OF MINOR ACTINIDES IN THE COMMERCIAL FUEL CYCLE
}

\author{
Compiled by \\ William D. Stanbro
}

\begin{abstract}
The minor actinide elements, particularly neptunium and americium, are produced as a normal byproduct of the operation of thermal power reactors. Because of the existence of longlived isotopes of these elements, they constitute the major sources of the residual radiation in spent fuel or in wastes resulting from reprocessing. Therefore, they are important contributors to the long-term radiological hazard of spent fuel and reprocessing wastes. This has led to examinations by some countries of the possibility of separating the minor actinides from waste products.

Historically, more attention has been devoted to understanding the behavior of the more common actinides uranium and plutonium in the fuel cycle. The papers found in this report are the result of an effort to rectify this imbalance. They address the production of minor actinides in common thermal power reactors as well as approaches to measure these materials in various media.

The first paper in this volume, "Production of Minor Actinides in the Commercial Fuel Cycle," uses calculations with the ORIGEN2 reactor and decay code to estimate the amounts of minor actinides in spent fuel and separated plutonium as a function of reactor irradiation and the time after discharge. The second paper, "Destructive Assay of Minor Actinides," describes a number of promising approaches for the chemical analysis of minor actinides in the various forms in which they are found at reprocessing plants. The next paper, "Hybrid KED/XRF Measurement of Minor Actinides in Reprocessing Plants," uses the results of a simulation model to examine the possible applications of the hybrid KED/XRF instrument to the determination of minor actinides in some of the solutions found in reprocessing plants. In "Calorimetric Assay of Minor Actinides," the authors show some possible extensions of this powerful technique beyond the normal plutonium assays to include the minor actinides. Finally, the last paper in this volume, "Environment Measurements of Transuranic Nuclides," discusses what is known about the levels of the minor actinides in the environment and ways to analyze for these materials in environmental matrices.

It is the hope of the authors that these papers will lead to a renewed interest in these materials. As shown by the computer models, the minor actinides are being produced in quantity by commercial power reactors. Therefore, we believe that understanding their behavior and how to measure them will prove not only interesting but, in the final analysis, of great utility.
\end{abstract}




\section{DISCLAMMER}

Portions of this document may be illegible in electronic image products. Images are produced from the best available original doccument. 


\title{
PRODUCTION OF MINOR ACTINIDES IN THE COMMERCIAL FUEL CYCLE
}

\author{
William D. Stanbro, Charles W. Nakhleh, and James M. Davidson \\ Nonproliferation and International Security Division \\ Los Alamos National Laboratory \\ Los Alamos, New Mexico
}

\section{INTRODUCTION}

The minor actinides are an inevitable by-product of the production of electricity with thermal reactors. This paper will review the mechanisms of production of the principal minor actinides $\left({ }^{237} \mathrm{~Np},{ }^{241} \mathrm{Am}\right.$, and $\left.{ }^{243} \mathrm{Am}\right)$ and their expected concentrations in spent fuel from commercial power reactors as well as in Pu produced from reprocessing these types of spent fuels. All the results shown are derived from calculations done using the ORIGEN2 reactor code. ${ }^{1}$

\section{REACTOR PRODUCTION}

Neptunium-237 is produced by the relatively rapid (6.75-d half-life) beta decay of ${ }^{237} U$. The ${ }^{237} \mathrm{U}$ is generated in a reactor by $\mathrm{n}, \gamma$ reactions either from lighter uranium isotopes ${ }^{235} \mathrm{U}$, ${ }^{236} \mathrm{U}$ ) or from ${ }^{238} \mathrm{U}$ by an $\mathrm{n}, 2 \mathrm{n}$ process. Once removed from the reactor, the quantities of ${ }^{237} \mathrm{~Np}$ remain essentially unchanged with time because of their long half-life $\left(2.14 \times 10^{6} \mathrm{y}\right){ }^{2}$

Americium-243 is produced by the very rapid $\left(4.98-\mathrm{h}\right.$ half-life) beta decay of ${ }^{243} \mathrm{Pu}$, which is itself formed by successive $\mathrm{n}, \gamma$ reactions starting from ${ }^{239} \mathrm{Pu}$. While not as long lived as ${ }^{237} \mathrm{~Np},{ }^{243} \mathrm{Am}$ (7950-yr half-life) quantities still do not change dramatically after discharge. $^{2}$

Americium-241, however, which is produced by the beta decay (13.2-yr half-life) of ${ }^{241} \mathrm{Pu}$ is different in that the quantities of this material grow steadily after discharge. ${ }^{2}$ The consequences of this situation will be considered further in Sections III and IV.

Figures 1,2, and 3 show the concentrations of these three minor actinides in fuel from three different common power reactor types: a pressurized water reactor (PWR), a boiling water reactor (BWR), and a CANDU reactor (a Canadian-designed, heavy-water, moderated and cooled reactor). The concentrations are shown as a function of burnup out to 50,000 $\mathrm{MWd} / \mathrm{tU}$ for the BWR and PWR burning 3.5\% enriched LEU, and out to $10,000 \mathrm{MWd} / \mathrm{tU}$ for the CANDU. In each case the relative concentrations of the actinides are ${ }^{237} \mathrm{~Np}>{ }^{243} \mathrm{Am} \geq{ }^{241} \mathrm{Am}$. Also, in each case production shows an induction period while concentrations of the precursors build up to their equilibrium values. At higher burnups, large quantities of ${ }^{237} \mathrm{~Np}$ and ${ }^{243} \mathrm{Am}$ will be present in spent fuel from PWR and BWR reactors at discharge. The lower concentrations of these materials in CANDU reactors are a result of the lower burnups possible with this type of reactor, and in the case of ${ }^{237} \mathrm{~Np}$ the lower initial ${ }^{235} \mathrm{U}$ (CANDU reactors use natural uranium fuel).

\section{SPENT FUEL}

As discussed in the last section, once removed from the reactor the concentrations of ${ }^{237} \mathrm{~Np}$ and ${ }^{243} \mathrm{Am}$ remain essentially stable. However, the ${ }^{241} \mathrm{Am}$ concentrations will continue to 
rise as the ${ }^{241} \mathrm{Pu}$ continues to decay. Figures 4,5 , and 6 show the changes in concentration of ${ }^{241} \mathrm{Pu}$ and ${ }^{241} \mathrm{Am}$ with time for fuel produced by PWR, BWR, and CANDU reactors with burnups of 35,$000 ; 35,000$; and 7,500 $\mathrm{MWd} / \mathrm{tU}$, respectively. These curves show significant changes in the ${ }^{241} \mathrm{Am}$ content with the maximum levels being achieved more then 70 years after discharge. The concentrations begin to fall after this point as the decay of the ${ }^{241} \mathrm{Am}$ (458-yr half-life $)^{2}$ comes to dominate the process.

\section{STORED PRODUCT PLUTONIUM}

In the normal PUREX process, all of the Am and part of the Np follows the fission products to the high-level waste in the first extraction step. Depending on the process details the remainder of the $\mathrm{Np}$ will follow either the $\mathrm{U}$ or Pu when these materials are separated. The $\mathrm{Np}$ is then usually extracted from these products, although small amounts of Np may remain in the $\mathrm{Pu}$ product.

However, as the precursor to ${ }^{241} \mathrm{Am}$ is a Pu isotope, it will not be removed by reprocessing, and ${ }^{241} \mathrm{Am}$ will continue to be produced in the product over time. Figures 7 and 8 show the buildup of ${ }^{241} \mathrm{Am}$ in plutonium separated from 35,000 MWd/tU PWR and BWR spent fuel. As in the parent spent fuel, the maximum levels are found more than 70 years after separation and reaches a significant proportion of the actinide present.

\section{CONCLUSION}

From the examples shown above, it is clear that substantial quantities of the minor actinides ${ }^{237} \mathrm{~Np},{ }^{241} \mathrm{Am}$, and ${ }^{243} \mathrm{Am}$ are produced in the normal operation of common power reactors. Further, these materials remain present (and grow in the case of ${ }^{241} \mathrm{Am}$ ) in the spent fuel. Even if reprocessed, the product Pu will soon come to produce significant amounts of ${ }^{241} \mathrm{Am}$ because of the decay of ${ }^{241} \mathrm{Pu}$.

\section{REFERENCES}

1. ORIGEN2, V2.1, Radiation Shielding Information Center, P. O. Box 2008, Oak Ridge, TN 37831-6362, August 1, 1991.

2. M. Benedict, T. H. Pigford, and H. W. Levi, Nuclear Chemical Engineering, 2nd Edition (McGraw-Hill, New York, 1981). 


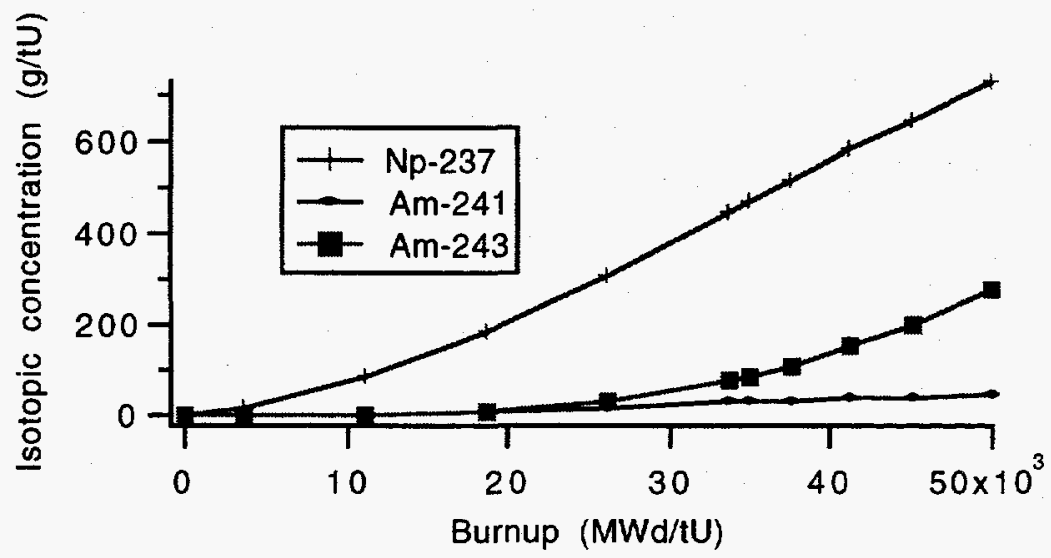

Figure $1 .{ }^{237} \mathrm{~Np},{ }^{241} \mathrm{Am}$, and ${ }^{243} \mathrm{Am}$ concentrations at discharge vs. burnup for a PWR.

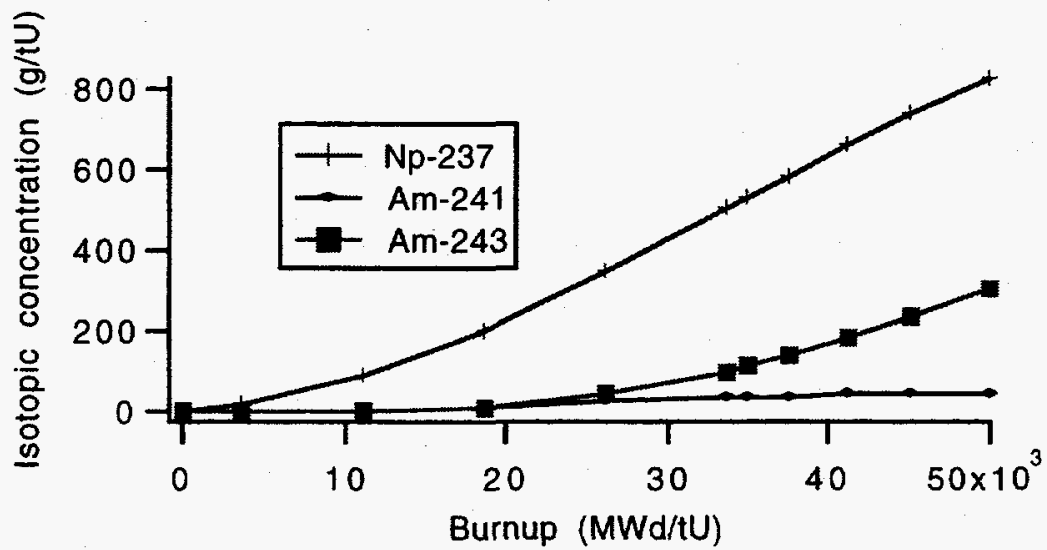

Figure $2 .{ }^{237} \mathrm{~Np},{ }^{241} \mathrm{Am}$, and ${ }^{243} \mathrm{Am}$ concentrations at discharge vs. burnup for a BWR.

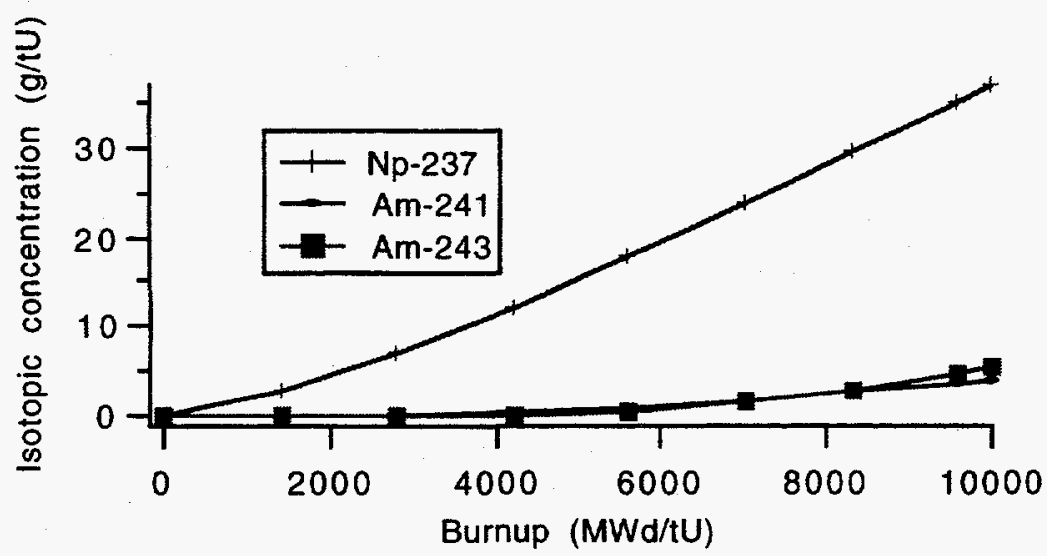

Figure $3 .{ }^{237} \mathrm{~Np},{ }^{24 l} \mathrm{Am}$, and ${ }^{243} \mathrm{Am}$ concentrations at discharge vs. burnup for a CANDU. 


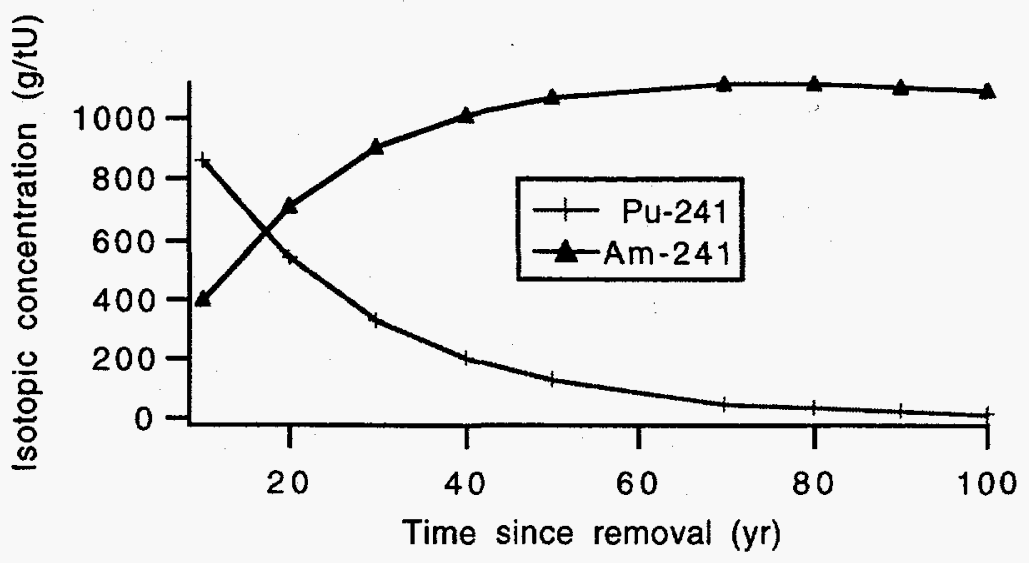

Figure 4. ${ }^{24 I} \mathrm{Pu}$ and ${ }^{241} \mathrm{Am}$ concentrations vs. time in $35,000 \mathrm{MWd} / \mathrm{U}$ PWR spent fuel.

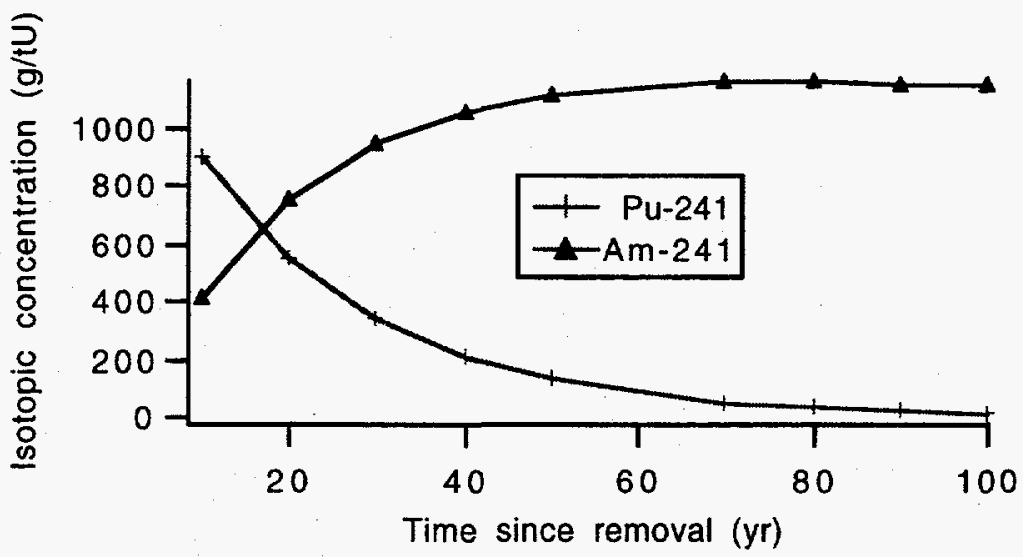

Figure 5. ${ }^{241} \mathrm{Pu}$ and ${ }^{241}$ Am concentrations vs. time in 35,000 MWdtU BWR spent fuel.

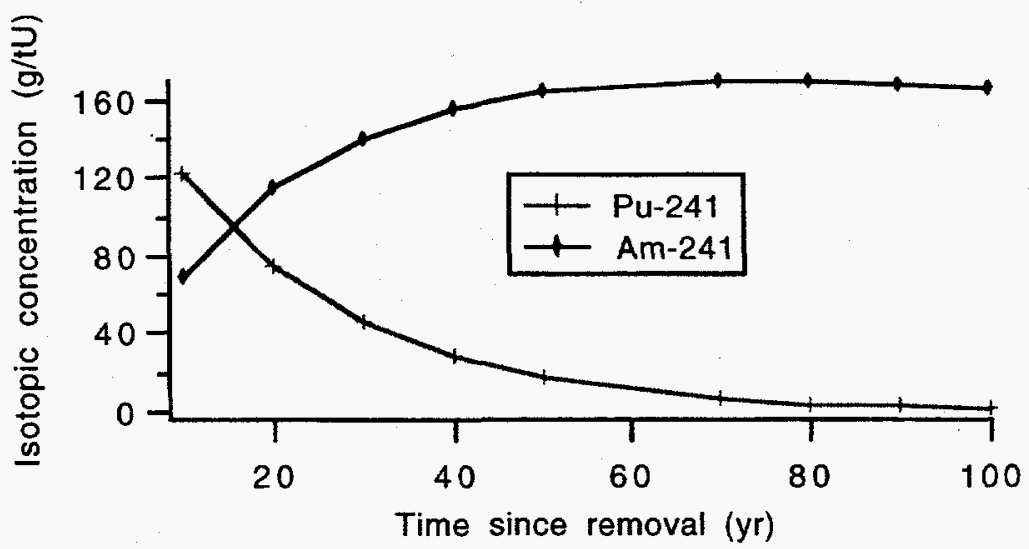

Figure. $6 .{ }^{241} \mathrm{Pu}$ and ${ }^{241} \mathrm{Am}$ concentrations vs, time in 7,500 MWd/tU CANDU spent fuel. 


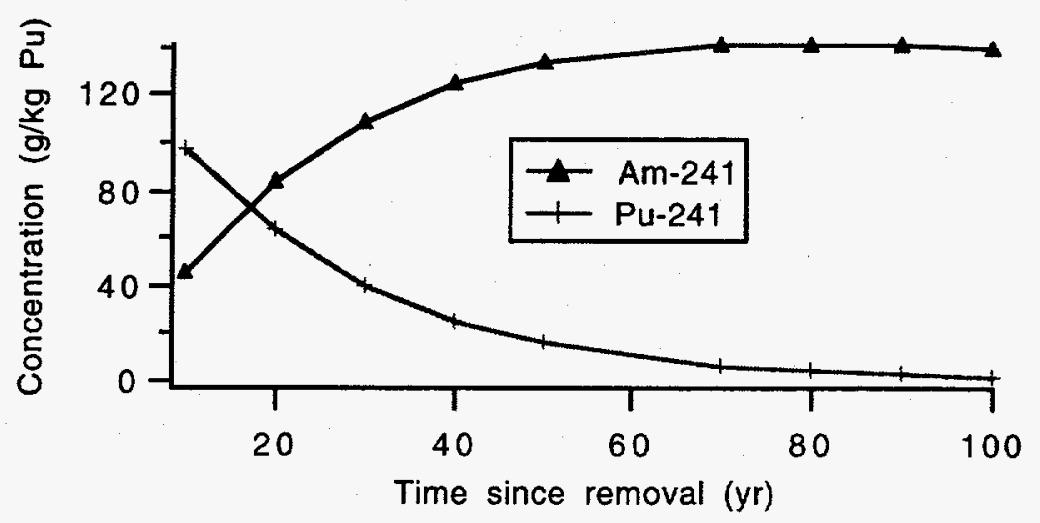

Figure. 7. $\quad{ }^{241} \mathrm{Pu}$ and ${ }^{241} \mathrm{Am}$ concentrations vs. time in Pu separated from 35,000 MWd/tU PWR spent fuel.

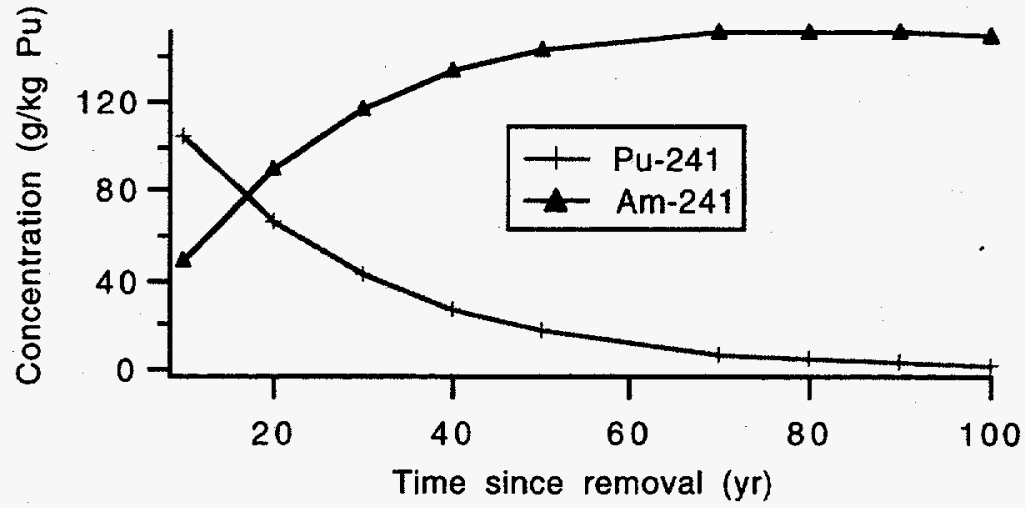

Figure. 8. $\quad{ }^{241} \mathrm{Pu}$ and ${ }^{241} \mathrm{Am}$ concentrations vs. time in Pu separated from 35,000 MWd/tU BWR spent fuel. 



\title{
DESTRUCTIVE ASSAY OF MINOR ACTINIDES
}

\author{
Darryl D. Jackson and Donald J. Temer \\ Advanced Nuclear Technology Group \\ Los Alamos National Laboratory \\ Los Alamos, New Mexico
}

Several issues need to be addressed in evaluating current capabilities and potential areas of fruitful R\&D activities for verification of minor actinides (MAs). There will be a need to measure MAs as separate products, mixed with plutonium and uranium, and in waste streams. Thus, measurement capabilities will be required for separated MAs, blends of MAs with plutonium and uranium in various matrices, and in waste streams.

For separated, pure plutonium and uranium materials and blends of the two, analytical chemistry methods are well developed. The analytical chemistry methods are isotopically independent and measure the total quantity of the element.

The most widely used method for uranium is based upon modifications of the DaviesGray titration. The method typically uses about $25 \mathrm{mg}$ uranium, is very selective, and is capable of precision of better than $0.1 \%$ RSD. As with many of the analytical chemistry methods, several steps are involved in the procedure, and a trained, skilled person is required for best results. The Davies-Gray titration has been automated at several laboratories, including Los Alamos.

Several methods are used for plutonium. Controlled-potential-coulometry is probably the most widely used procedure; it offers features of small sample size (5 mg), good precision (typically better than $0.1 \%$ RSD), very good selectivity, and few operations. Typically the oxidation of $\mathrm{Pu}$ (III) to $\mathrm{Pu}$ (IV) in sulfuric acid electrolyte is the measurement step. Iron interferes and a correction must be made for iron. We have automated the controlled-potentialcoulometric method for plutonium. The MacDonald-Savage amperometric titration procedure, developed for measuring plutonium in reprocessing solutions, provides good selectivity and precision with a small sample. For a sample size of about $5 \mathrm{mg}$, precision is typically about $0.1 \%$ RSD. The method has many steps but has been automated for the IAEA Safeguards Analytical Laboratory. Neptunium interferes; it must be measured independently and a correction applied. Spectrophotometric methods are widely used; the Pu(III) spectra is usually used in chloride systems and the Pu(VI) spectra in nitrate systems. We routinely use both methods. We have automated the measurement step for the $\mathrm{Pu}(\mathrm{VI})$ method, thereby reducing analyst time and attention. The spectrophotometric methods are selective and capable of precision of about $0.25 \%$ RSD. Online fiber-optic spectrophotometric systems have been developed for monitoring process lines for plutonium and uranium concentration and valence states.

For pure separated neptunium, controlled-potential-coulometry can be used. Neptunium is oxidized to $N p(V I)$ chemically, the excess oxidant destroyed, and the $N p(V I)$ reduced to $\mathrm{Np}(\mathrm{V})$ electrolytically. The electrolytic oxidation of $\mathrm{Np}(\mathrm{V})$ to $\mathrm{Np}(\mathrm{VI})$ is the measurement step. For a sample size of about $5 \mathrm{mg}$, precision is typically about $0.1 \% \mathrm{RSD}$. We have developed spectrophotometric methods for measuring neptunium. The $N p(V)$ spectra is used in chloride systems and the $N p(V I)$ spectra in nitric acid. The $N p(V)$ peak is very sharp and in a spectral region removed from most potentially interfering species. Precision is typically about $0.25 \%$ RSD. 
A controlled-potential-coulometric method based upon oxidation of Am(III) to Am(IV) has been described for americium, but radiolysis of the electrolyte can cause high background currents that negatively affect the determination. We have developed a spectrophotometric method based upon the Am(Ill) spectra. Analytical methods for measuring americium with high precision require development. The most promising approaches are based upon further development of spectrophotometric methods using the Am(III) spectra.

Methods need to be developed for measuring MAs not separated from uranium and plutonium. For verification, the ratio of neptunium and americium to uranium and plutonium could possibly be measured on the same solution spectrophotometrically without requiring a separation. Neptunium, americium, and plutonium in the appropriate oxidation state and matrix all have very sharp absorption peaks. Adjusting the oxidation state and measuring the absorption spectra could give Pu/Np and Pu/Am directly. A recently described method uses a secondorder derivative spectrophotometric method to measure small quantities of americium in nitric acid solutions containing uranium and plutonium. Precision was about 2\% RSD. Methods based upon this type of approach need to be pursued. Areas of investigation would include oxidation state, solution matrix, and spectral region. A two-step procedure may be required on the same solution to avoid spectral interference. For example, measure spectra under one set of conditions, oxidize or change matrix, and measure the spectra again. In the worst case, a separation may be required. Separation methods are available, but increase the time and effort. We have demonstrated that controlled-potential-coulometry can be used to assay plutonium containing up to $10 \%$ neptunium and neptunium containing up to $10 \%$ plutonium with no interference under appropriate conditions. The effect of larger quantities has not been investigated. The electrode potentials are close, but it may be possible to find electrolysis conditions that allow both plutonium and neptunium to be measured on the same solution.

Isotope dilution mass spectrometry can be used for plutonium, uranium, and americium; it requires separation of the elements.

Standards are needed to establish and demonstrate measurement capabilities for both nondestructive assay and destructive assay. Standards will be required for calibration and measurement control. Standards are available for pure, separated uranium and plutonium, but they must be prepared for MAs and mixtures. Required standards need to be identified as soon as possible to allow time for preparation, characterization, and packaging.

Spectrophotometric methods may be suitable for monitoring waste streams. It may be possible to monitor continuously, but probably it will require sampling at intervals and measuring the samples to meet the sensitivity requirements.

The measurement methods for MAs require further development. In most cases, little is known about interferences, matrix effects, or accuracy. These need to be established.

Analytical chemistry methods require laboratory skills and modest instrumentation-no major change. Instruments required for controlled-potential-coulometry are generally available. High resolution spectrophotometers are generally available. Other items are basic, relatively inexpensive laboratory items such as analytical balances and sample changers. 


\title{
HYBRID KED/XRF MEASUREMENT OF MINOR ACTINIDES \\ IN REPROCESSING PLANTS
}

\author{
S.-T. Hsue and M. L. Collins \\ Safeguards Science and Technology Group \\ Los Alamos National Laboratory \\ Los Alamos, New Mexico
}

\section{INTRODUCTION}

Minor actinides have received considerable attention recently in the nuclear power industry. Because of their potential value as recycle fuels in thermal and breeder reactors, reprocessing plants may have an economic incentive to extract neptunium, americium, and curium from their waste streams. ${ }^{1}$

This report discusses the technique of hybrid densitometry and its potential to measure neptunium and americium in reprocessing plants. Precision estimates are made for the hybrid analysis of neptunium and americium in two types of dissolver solutions.

\section{HYBRID SYSTEM}

The hybrid system incorporates two solution assay techniques: k-edge absorption densitometry (KED) and x-ray fluorescence (XRF). A close-up view of the Los Alamos Hybrid Densitometer is shown in Figure 1. The basic components of the hybrid system are an X-ray generator, glass sample vial, and separate high-resolution detectors for KED and XRF. The sample itself may contain any number of actinides dissolved in nitric acid.

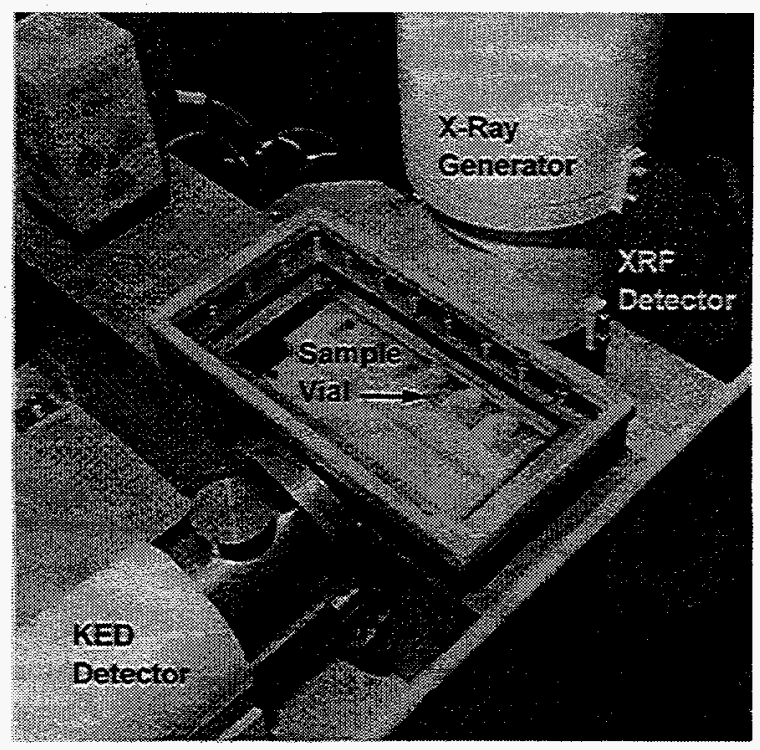

Figure 1. Close-up view of Los Alamos Hybrid Densitometer System. 
The $\mathrm{X}$-ray generator irradiates the sample with a filtered $\mathrm{x}$-ray beam. The KED detector is positioned behind the sample, and measures the transmitted portion of the beam. The XRF detector is positioned behind a long, narrow collimator that points toward the front of the sample vial. The angle between the incident beam and XRF collimator is 30 degrees. The $\mathrm{XRF}$ detector measures fluoresced $\mathrm{x}$-rays that are emitted from the front portion of the solution.

In hybrid analysis, KED is used to determine the concentration of the major element, usually uranium or plutonium. XRF is used to determine various ratios of concentrations, such as $\mathrm{U} / \mathrm{Pu}, \mathrm{Pu} / \mathrm{Am}$, and $\mathrm{Pu} / \mathrm{Np}$. Measured ratios are used to determine the ratio of each minor element to the major element. It is then a simple matter to calculate the concentrations of the minor elements. Hybrid analysis takes advantage of the strengths of the KED and XRF techniques.

\section{PROCESS FLOW}

The process flow for a conventional reprocessing plant is illustrated in Figure 2. Spent fuel is placed in the fuel storage facility prior to reprocessing. In the first stage of reprocessing, fuel rods are chopped into small pieces. The resulting mixture is leached in nitric acid to form the dissolver solution. Most fission products and Am are removed in the first extraction cycle. Additional extraction steps are required to separate uranium and plutonium from the remaining elements. Evaporation is performed to concentrate the uranium and plutonium solutions, forming the product solutions.

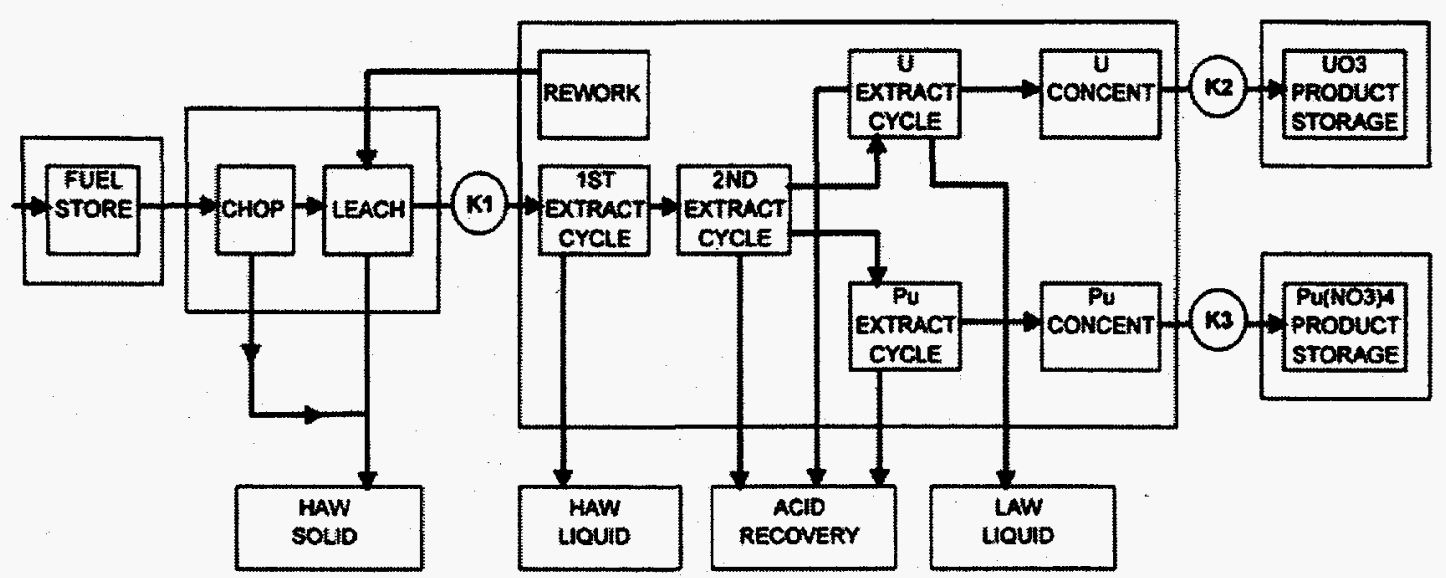

Figure 2. Process flow schematic for a conventional reprocessing plant. Key measurement points are labeled $K 1$ through $K 3$.

IAEA and Euratom have been using the hybrid KED/XRF technique to assay the dissolver solution samples, and KED to assay the uranium and plutonium product solutions. The dissolver solution is monitored at key measurement point $\mathrm{K} 1$. The uranium and plutonium product solutions are monitored at key measurement points $\mathrm{K} 2$ and $\mathrm{K} 3$, respectively. By measuring uranium and/or plutonium concentrations at these three measurement points, it is possible to determine the material balance of uranium and plutonium. 
If a reprocessing plant extracted americium and neptunium, its process flow might resemble that of Figure 3. In this scenario, Am would be separated from the high-activity effluent of the first extraction cycle. Neptunium would be separated from the effluent of the plutonium extraction cycle. Evaporation steps would be performed to concentrate the americium and neptunium solutions. Such a plant would have four product solutions: uranium, plutonium, neptunium, and americium.

As in the conventional reprocessing plant, the dissolver solution would be monitored at key measurement point $\mathrm{K} 1$. A hybrid KED/XRF densitometer would be used to measure the uranium, plutonium, neptunium, and americium concentrations in the dissolver solution. The neptunium and americium product solutions are monitored at key measurement points K4 and $\mathrm{K} 5$, respectively. By measuring the neptunium and/or americium concentrations at these three measurement points, it would be possible to determine the material balance of neptunium and americium.

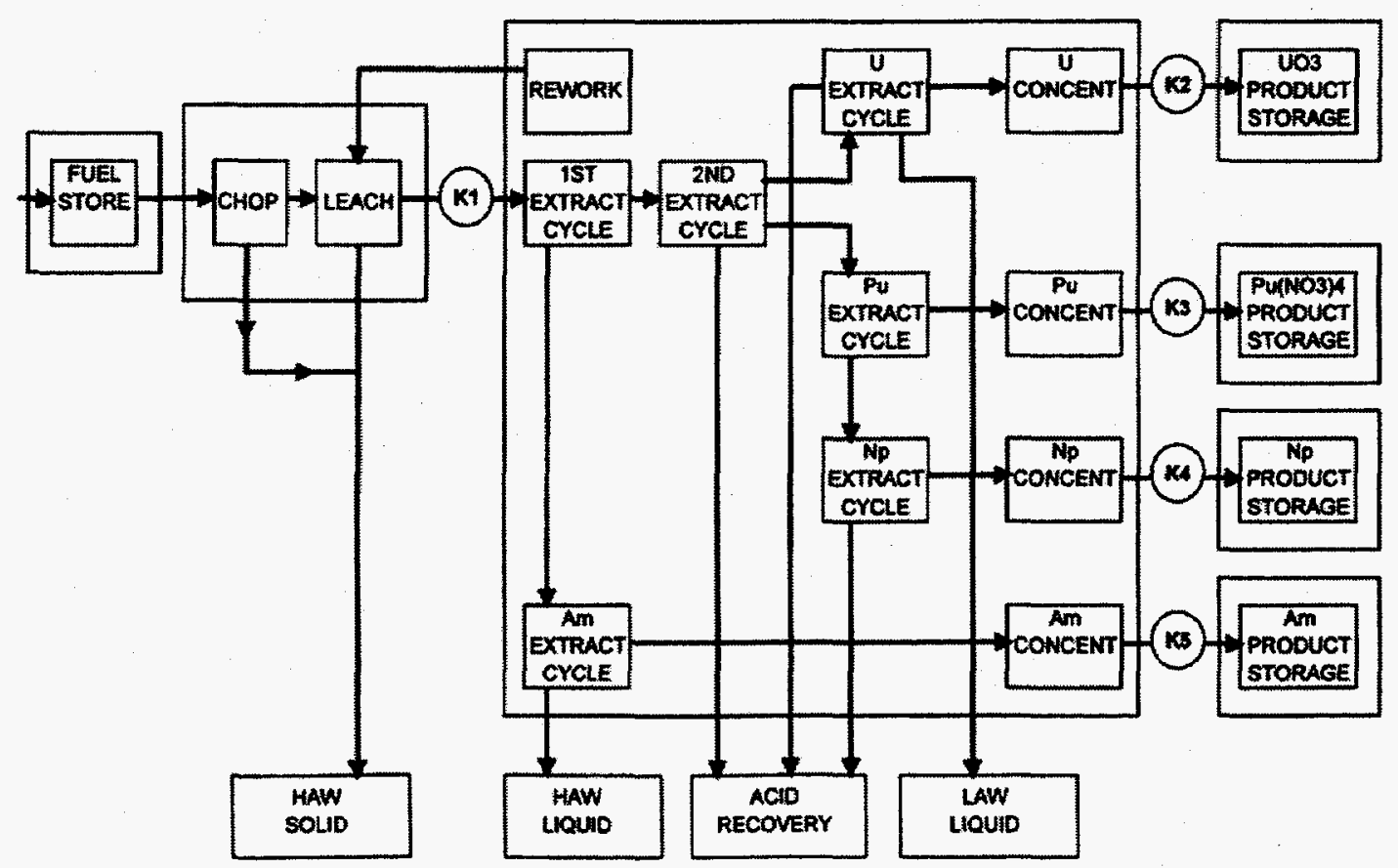

Figure 3. Process flow for a hypothetical reprocessing plant, showing separation of neptunium and americium. Key measurement points are labeled KI through $K 5$.

\section{DISSOLVER SOLUTIONS}

In this study, two types of dissolver solutions were considered. The first is from a fast breeder reactor (FBR) reprocessing plant; the other from a light water reactor (LWR) reprocessing plant. These solutions are characterized in Table 1. 


\begin{tabular}{|c|c|c|}
\hline & $\begin{array}{c}\text { FBR } \\
\text { Dissolver }\end{array}$ & LWR Dissolver \\
\hline $\mathrm{U}$ Concentration $(\mathrm{g} / \mathrm{l})$ & 200 & 200 \\
\hline Pu Concentration $(\mathrm{g} / \mathrm{l})$ & 50 & 2 \\
\hline Pu/Np Ratio & 10 & 30 \\
\hline Pu/Am Ratio & 10 & 30 \\
\hline
\end{tabular}

We have developed computer codes that simulate the performance of the hybrid system. ${ }^{2,3}$ These codes generate KED and XRF spectra that correspond to a given solution. Simulated spectra for the FBR and LWR dissolver solutions are illustrated below. All simulated spectra in this study correspond to a live time of 1000 seconds.

Figure 4 shows the KED reference spectrum and simulated KED spectra for FBR and LWR dissolver solutions. The $\mathrm{K}$ absorption edge of uranium (at $115.606 \mathrm{keV}$ ) is clearly visible in both the FBR and LWR spectra. The K absorption edge of plutonium (at 121.797 $\mathrm{keV}$ ) is prominent in the FBR spectrum, but not in the LWR spectrum.

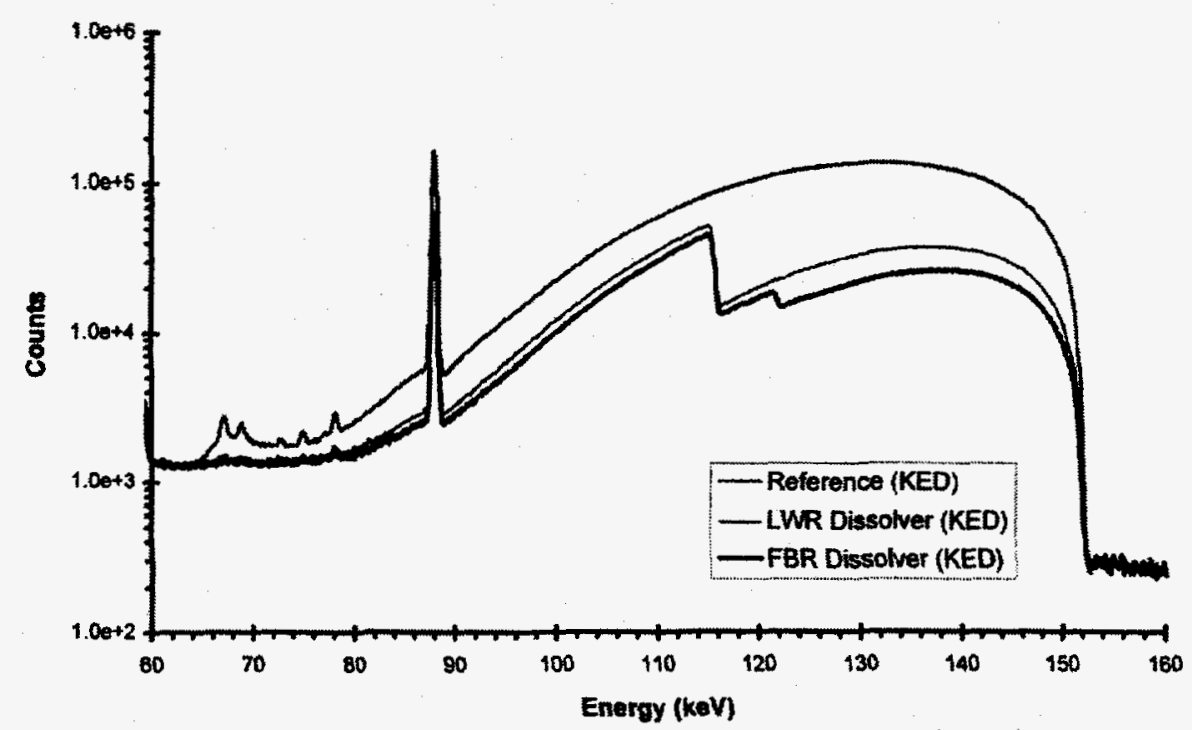

Figure 4. Simulated KED spectra for FBR and LWR dissolver solutions. Reference spectrum is uppermost trace in graph.

The differences between the FBR and LWR spectra are more readily observed if the spectra are plotted in $\operatorname{LnLn}(1 /$ Transmission) vs $\operatorname{Ln}$ (Energy) space. Because of the energy dependence of mass attenuation coefficients, we expect measured data to be linear on either side of each absorption edge in $\operatorname{LnLn}(1 / T)$ vs $\operatorname{Ln}($ Energy) space. This can be seen in Figure 5 . Single-element KED analysis is performed by doing a linear fit in this space, using regions above and below the edge. The concentration of the element is calculated using the results of the linear fitting. 
In Figure 5, the uranium and plutonium edges are prominent for the FBR dissolver solution. Very small neptunium and americium edges can also be observed in the FBR data. In the LWR data, a plutonium edge can hardly be spotted, and the neptunium and americium edges are unidentifiable.

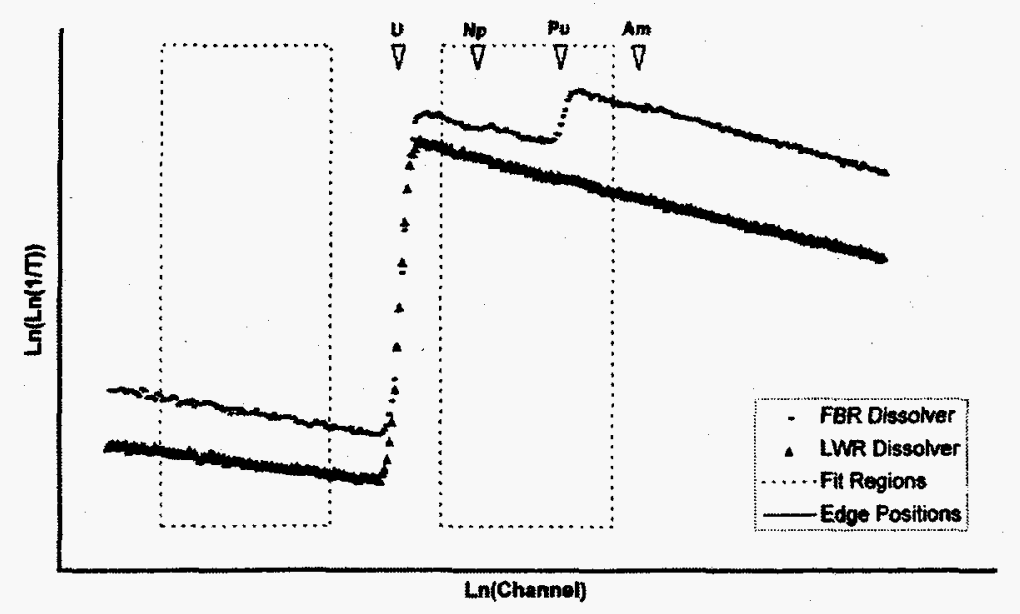

Figure 5. Simulated KED spectra for FBR and LWR dissolver solutions, plotted in $\operatorname{Ln} \operatorname{Ln}(1 / T)$ vs $L n(E n e r g y)$ space. Positions of absorption edges are marked.

Figure 6 shows the XRF reference spectrum and simulated XRF spectra for FBR and LWR dissolver solutions. For each element present in a simulated solution, $10 \mathrm{x}$-ray peaks are generated. These include the $K_{\alpha 1}, K_{\alpha 2}$, and $K_{\alpha 3}$ peaks, and various $K_{\beta}$ peaks. Several of the $40 \mathrm{x}$-ray peaks simulated in the dissolver solutions can be observed in Figure 6 . The $\mathrm{K}_{\alpha}$ peaks are seen below $108 \mathrm{keV}$ and the $K_{R}$ peaks are found above $110 \mathrm{keV}$.

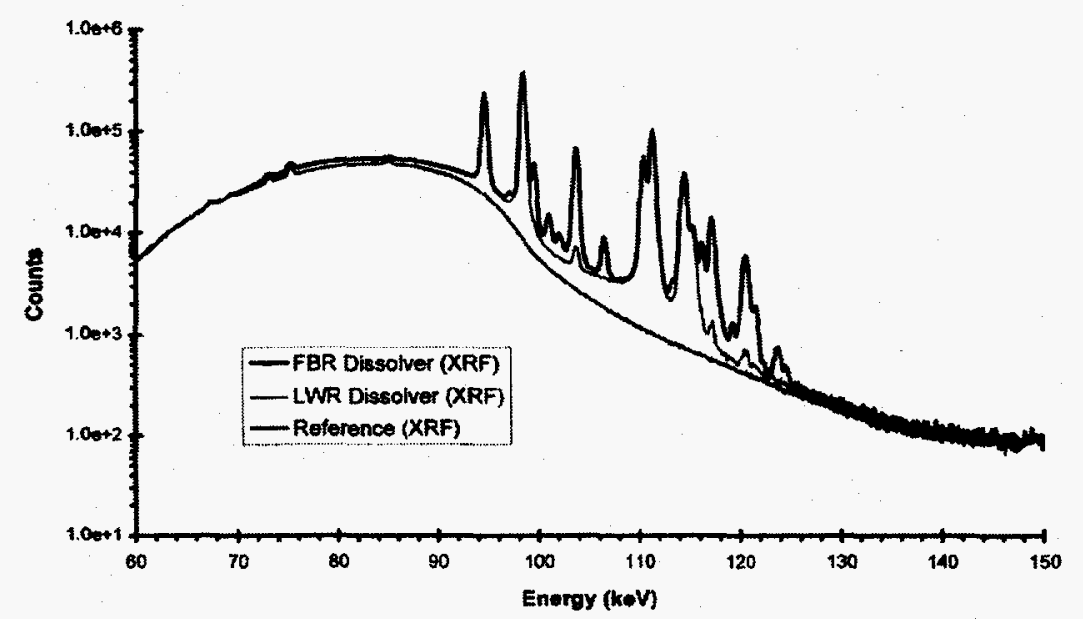

Figure 6. Simulated XRF spectra for FBR and LWR dissolver solutions. Reference spectrum is lowest trace on graph. 
The $\mathrm{K}_{\alpha}$ peaks are of primary interest in XRF analysis. Figure 7 compares the simulated FBR and LWR spectra, shown with the reference spectrum subtracted. The range of energies was narrowed to feature the $K_{\alpha}$ peaks of uranium, neptunium, plutonium, and americium. Note that the uranium $K_{\alpha}$ peaks of the FBR spectrum are slightly smaller than those of the LWR spectrum. This is due to attenuation effects within the FBR dissolver solution, which contains more plutonium, neptunium, and americium.

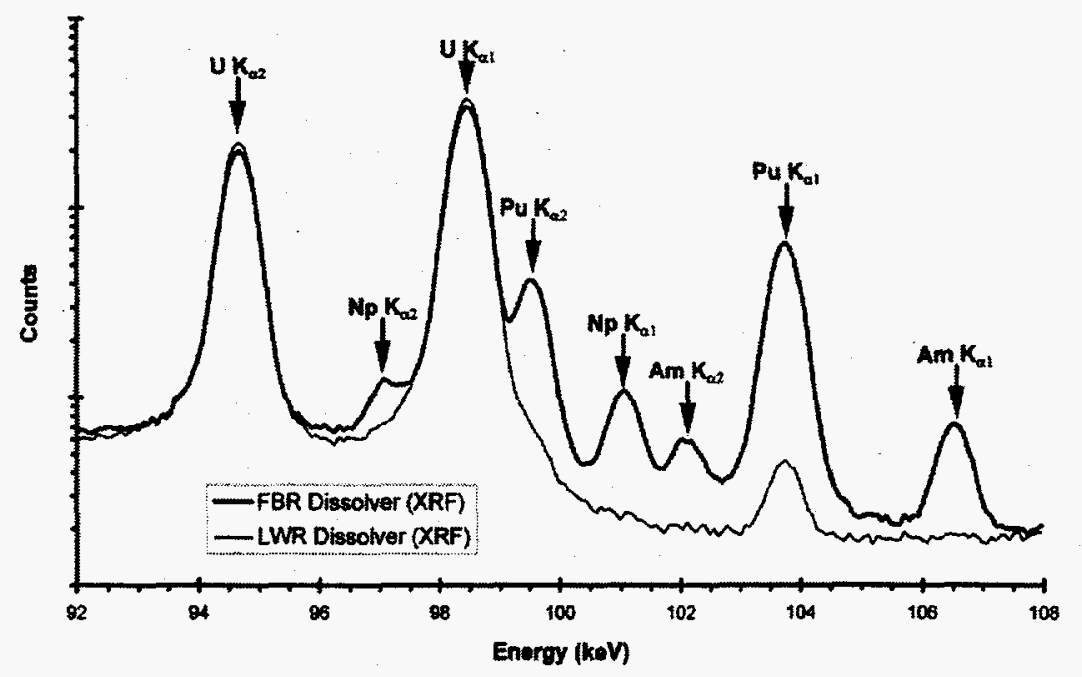

Figure 7. Comparison of XRF spectra for FBR and LWR dissolver solutions. Reference spectrum was subtracted from both series.

The Pu $\mathrm{K}_{\alpha}$ peaks in the FBR spectrum have a significantly greater area than those in the LWR spectrum because there is much more plutonium to fluoresce in the FBR dissolver solution. Similar observations can be made regarding the $K_{\alpha}$ peaks of neptunium and americium. In the LWR dissolver solution spectrum, the $\mathrm{K}_{\alpha} \mathrm{x}$-rays of neptunium and americium cannot be distinguished from noise.

\section{ESTIMATED PRECISION}

Hybrid analysis was performed on the simulated FBR and LWR dissolver solution spectra. First, the XRF spectra were analyzed to determine the percent uncertainties in the $\mathrm{U} / \mathrm{Pu}, \mathrm{Pu} / \mathrm{Np}$, and $\mathrm{Pu} / \mathrm{Am}$ ratios. Then the KED spectra were analyzed to determine the percent uncertainty in the concentration of the major element.

In KED analysis, the fixed ratio technique was used. ${ }^{4}$ This technique utilizes U/Pu, $\mathrm{Pu} / \mathrm{Np}$, and $\mathrm{Pu} / \mathrm{Am}$ ratios to mathematically strip out the attenuation effects of minor elements in the solution. Single-element KED analysis is performed on the deattenuated spectrum to determine the concentration of the major element in the solution. In this study, the actual ratios known from simulation were used in the fixed-ratio technique.

Hybrid results for FBR and LWR dissolver solutions are shown below in Table 2 . Uranium was the major element in KED analysis for both dissolver solutions. 


\begin{tabular}{|c|c|c|}
\hline \multicolumn{3}{|c|}{$\begin{array}{c}\text { Table 2. Estimated Hybrid Precision for FBR and } \\
\text { LWR Dissolver Solutions }\end{array}$} \\
\hline \hline & FBR Dissolver & LWR Dissolver \\
\hline \hline $\mathrm{KED} \mathrm{s}(\mathrm{U})$ & $0.2 \%$ & $0.2 \%$ \\
\hline $\mathrm{XRF} \mathrm{s}(\mathrm{U} / \mathrm{Pu})$ & $0.2 \%$ & $1.4 \%$ \\
\hline $\mathrm{XRF} \mathrm{s}(\mathrm{Pu} / \mathrm{Np})$ & $0.8 \%$ & N/A \\
\hline $\mathrm{XRF} \mathrm{s}(\mathrm{Pu} / \mathrm{Am})$ & $0.9 \%$ & N/A \\
\hline
\end{tabular}

With the FBR dissolver solution, the $\mathrm{x}$-ray peaks of neptunium and americium were readily identified and measured by the XRF analysis code. No sample preparation is needed for the FBR dissolver solution.

The situation is different for the LWR dissolver solution. Recall that in Figure 7 , the $\mathrm{K}_{\alpha}$ peaks of neptunium and americium in the LWR spectrum were indistinguishable from noise. This was verified by the XRF analysis code, which did not detect the presence of neptunium or americium in the LWR dissolver solution. We therefore cannot expect to measure neptunium or americium in the straight LWR dissolver solution using the hybrid technique.

In order for the hybrid system to measure neptunium and americium at key measurement point $\mathrm{K} 1$ in the LWR reprocessing plant, some preparation of the dissolver solution sample would be required. This would involve chemical separation to remove most of the uranium from the dissolver solution. Evaporation would also be needed to concentrate the remaining liquid several-fold. In this study, three preparation scenarios were considered for the LWR dissolver solution. These are detailed in Table 3 below.

\begin{tabular}{|r|c|c|c|}
\hline Table 3. Possible Preparations of LWR Dissolver Solution \\
\hline \hline & Solution 1 & Solution 2 & Solution 3 \\
\hline \hline Separation Quality & Fair & Good & Excellent \\
\hline U Removal & $97.0 \%$ & $99.0 \%$ & $99.9 \%$ \\
\hline Evaporation Factor & 20 & 20 & 50 \\
\hline Known U (g/1) & 120 & 40 & 10 \\
\hline Known Pu (g/1) & 40 & 40 & 100 \\
\hline
\end{tabular}

Simulated KED and XRF spectra were generated for the above solutions. Hybrid analysis, as described earlier, was performed on the simulated spectra. The major element in KED analysis was uranium for solution 1 and plutonium for solutions 2 and 3 . The results for the prepared LWR solutions are shown in Table 4.

\begin{tabular}{|c|c|c|c|}
\hline Table 4. & \multicolumn{3}{|c|}{$\begin{array}{l}\text { Estimated Hybrid Precision for Prepared LWR } \\
\text { Solutions }\end{array}$} \\
\hline \hline & Solution 1 & Solution 2 & Solution 3 \\
\hline \hline $\mathrm{KED} \sigma(\mathrm{U})$ & $0.2 \%$ & - & - \\
\hline $\mathrm{KED} \sigma(\mathrm{Pu})$ & - & $0.5 \%$ & $0.2 \%$ \\
\hline $\mathrm{XRF} \sigma(\mathrm{U} / \mathrm{Pu})$ & $0.2 \%$ & $0.3 \%$ & $0.4 \%$ \\
\hline $\mathrm{XRF} \sigma(\mathrm{Pu} / \mathrm{Np})$ & $2.3 \%$ & $2.1 \%$ & $1.0 \%$ \\
\hline $\mathrm{XRF} \sigma(\mathrm{Pu} / \mathrm{Am})$ & $2.4 \%$ & $2.2 \%$ & $1.1 \%$ \\
\hline
\end{tabular}




\section{v. CONCLUSIONS}

Hybrid KED/XRF densitometer systems now in operation at reprocessing plants have the potential to measure neptunium and americium, in addition to uranium and plutonium. No hardware alterations would be required in these systems. However, the analysis software would need to be upgraded. New hybrid analysis techniques for measuring neptunium and americium would be incorporated.

At an FBR reprocessing plant, neptunium and americium could be measured in dissolver solution samples with no sample preparation. The estimated precision for a 1000 -s assay is $0.8 \%$ for neptunium and $0.9 \%$ for americium.

At an LWR reprocessing plant, dissolver solution samples would require some preparation. This preparation would involve partial uranium separation (97\% to $99.9 \%$ removal), and evaporation ( 20 to 50 fold concentration). The estimated precision for a $1000 \mathrm{~s}$ assay ranges from $1.0 \%$ to $2.3 \%$ for neptunium and from $1.1 \%$ to $2.4 \%$ for americium. The precision depends upon the extent of sample preparation.

\section{REFERENCES}

1. J. E. Stewart, R. B. Walton, et al., "Measurement and Accounting of the Minor Actinides Produced in Nuclear Power Reactors," Los Alamos National Laboratory report LA-13054MS, pp. 2-3 (January 1996).

2. M. L. Collins and S.-T. Hsue, "Simulation of X-Ray Fluorescence Spectra," Los Alamos National Laboratory report LA-UR-96-2603 (to be published in 37th Annual Nuclear Materials Management, Proceeding Issue).

3. S.-T. Hsue and M. L. Collins, "Simulation of Absorption Edge Densitometry," Los Alamos National Laboratory report LA-12874-MS (November 1994).

4. S.-T. Hsue and M. L. Collins, "New Analysis Technique for K-Edge Densitometry Spectra," Los Alamos National Laboratory report LA-UR-95-3222. Proceedings of the Fifth International Conference on Facility Operations-Safeguards Interface, American Nuclear Society, Jackson Hole, Wyoming, September 1995. 


\title{
CALORIMETRIC ASSAY OF MINOR ACTINIDES*
}

\author{
C. Rudy, D. Bracken, T. Cremers, L. A. Foster, and N. Ensslin \\ Los Alamos National Laboratory \\ Los Alamos, New Mexico
}

\begin{abstract}
This paper reviews the principles of calorimetric assay and evaluates its potential application to the minor actinides. We conclude that calorimetry and high-resolution gamma-ray isotopic analysis can be used for the assay of minor actinides by adapting existing methodologies for $\mathrm{Pu} / \mathrm{Am}-241$ mixtures. In some cases, mixtures of special nuclear materials and minor actinides may require the development of new methodologies that involve a combination of destructive and nondestructive assay techniques.
\end{abstract}

\section{INTRODUCTION}

Calorimetry is an important nondestructive assay (NDA) technique used for nuclear materials accountability and for accurate shipper/receiver measurements in most DOE plutonium and tritium facilities. Calorimeters are currently in use in DOE facilities such as Hanford, Pacific Northwest Labs, Lawrence Livermore, Sandia Livermore, Rocky Flats, Los Alamos, Savannah River, Mound, Idaho, and Pinellas. Also, calorimetry is now coming into use by the IAEA at the Westinghouse Hanford Site for bias-defects quality measurements of excess weapons materials. Calorimetry can determine sample power to about $0.2 \%$ for samples that emit more than 1 watt of thermal power. High-resolution gamma-ray spectroscopy or mass spectroscopy is used in conjunction with calorimetry to convert the measured sample power to total grams of plutonium. The combination of calorimetry and isotopic analysis is usually the most accurate NDA technique available for accountability measurements in a facility environment.

Most of the minor actinides that occur in the nuclear fuel cycle generate enough specific heat to make calorimetry a potentially viable technique for quantification. In some cases, the heat output is low enough to require very sensitive calorimeters and careful gamma-ray isotopic analysis. This paper reviews the principles of calorimetric assay and evaluates its potential application to the minor actinides.

\section{PRINCIPLES OF CALORIMETRIC ASSAY}

An isothermal calorimeter measures the constant heat output of nuclear material by allowing the sample to come to equilibrium in a constant temperature environment. Fine nickel wires in a Wheatstone bridge arrangement are used to measure the temperature rise through a calibrated thermal resistance $\left({ }^{\circ} \mathrm{C} / \mathrm{watt}\right)$. Once the sample thermal power is determined, it is converted to mass using the sample specific power Peff, as follows:

"This work is supported by the US Department of Energy, Office of Arms Control and Nonproliferation. 


$$
\text { MASS (grams) }=\frac{\text { POWER (watts) }}{P_{\text {eff }} \text { (watt/gram) }}
$$

The sample specific power is the sum of the specific powers of the isotopes that make up the sample as follows:

$$
P_{\text {eff }} \text { (watts/gram) }=\Sigma_{i} R_{i} P_{i},
$$

where $\mathbf{R}_{\mathbf{i}}=$ mass fraction of isotope $\mathrm{i}$,

$P_{i}=$ specific power (watts/gram) of isotope $\mathrm{i}$.

Gamma-ray or mass-spectroscopy isotopic information is needed to determine the mass fractions of each isotope present in the sample.

Figure 1 shows a water-bath calorimeter developed by Mound Laboratories, and in common use throughout DOE facilities. The water bath is used to control the temperature of the calorimeter's environment. This water bath contains two twin 7-inch-diameter calorimeters of the type used by Westinghouse Hanford for nuclear materials accountability and for IAEA inspections of excess weapons materials.

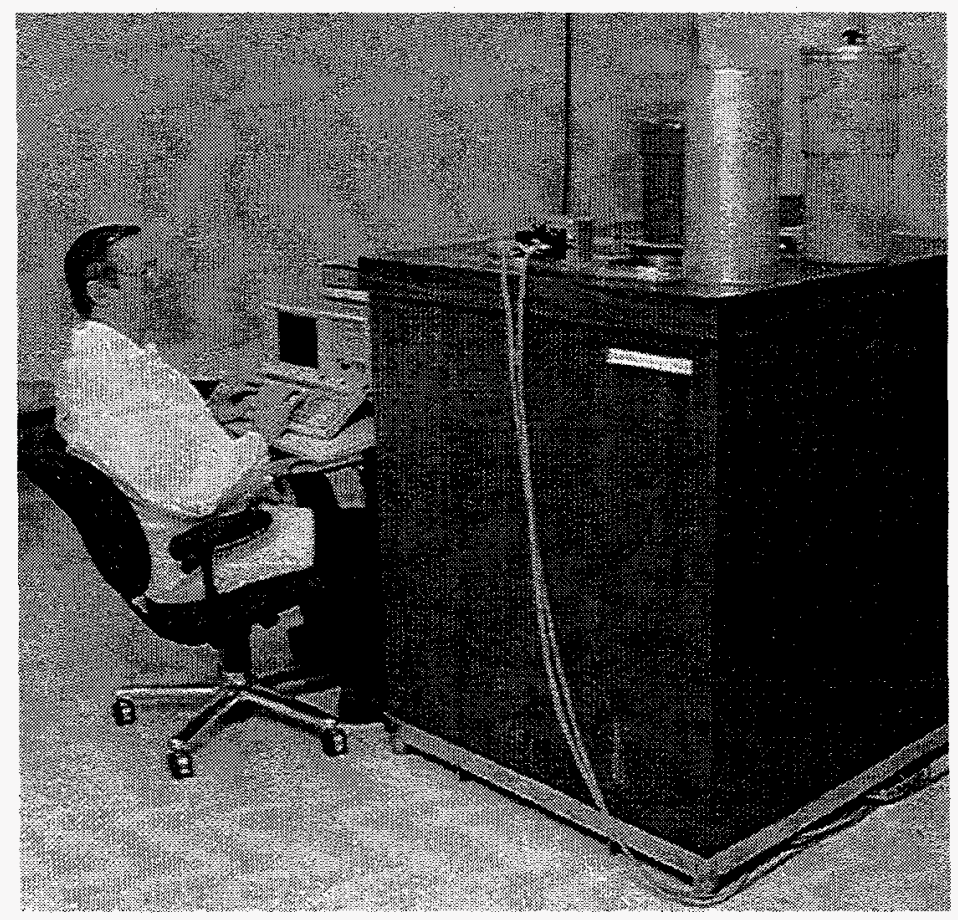

Figure 1. A water-bath calorimeter developed by Mound Laboratories and in common use throughout DOE facilities. The water bath contains a pair of twin calorimeters of the type used by Westinghouse Hanford for IAEA inspections of excess weapons materials. 
Figure 2 shows a sensitive, transportable calorimeter developed recently by Mound Laboratories. This calorimeter is currently being used for measurements of highly enriched uranium (HEU), which emits only low amounts of heat, primarily from the U-234 that accompanies the U-235 in HEU. ${ }^{1}$ A calorimeter of this type would be sufficiently sensitive and transportable to be suitable for IAEA measurements in a nuclear facility.

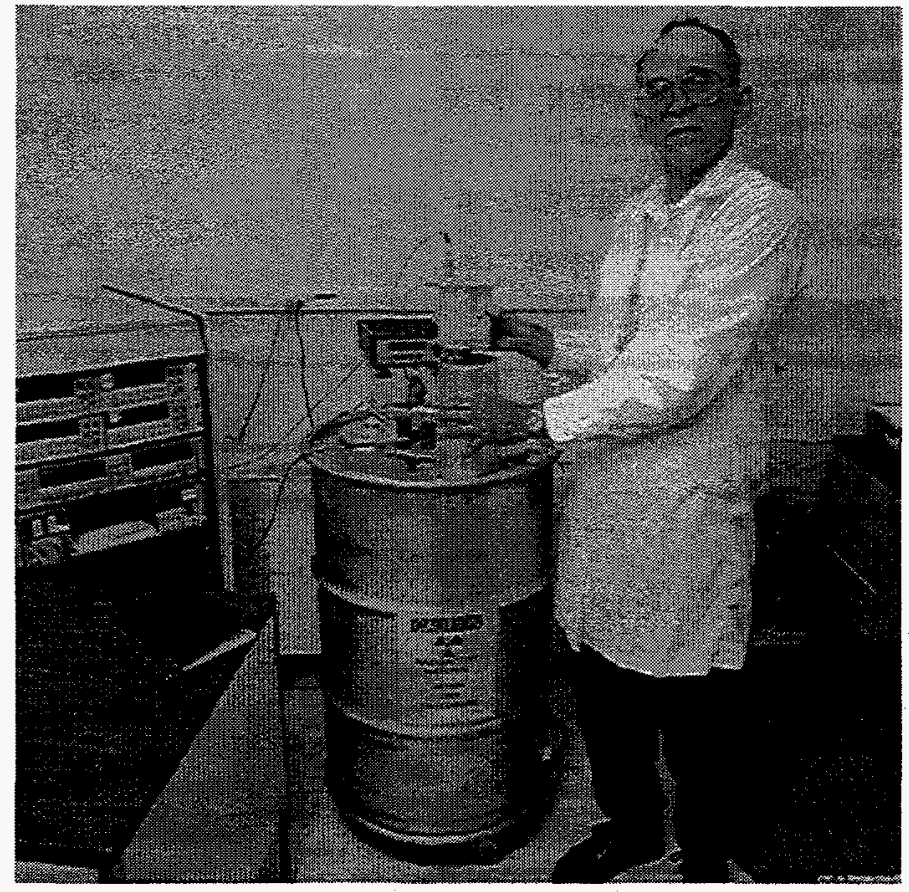

Figure 2. A sensitive, transportable calorimeter developed at Mound Laboratories. This calorimeter is currently being used for measurements of HEU and would be suitable for IAEA measurements in a nuclear facility.

Important features of calorimetric assay include the following:

1. Sample power is routinely measured to an accuracy of $0.2 \%$ for high thermal power samples. Including the measurement error due to gamma-ray isotopic analysis, the accuracy of calorimetry/isotopics is typically 0.3 to $1.0 \%$.

2. No physical standards are required. The calorimeter is calibrated relative to $\mathrm{Pu}-238$ heat sources.

3. The measurement is matrix independent.

4. The measurement is traceable to the national measurement system through the $\mathrm{Pu}-$ 238 heat source calibration and certification process.

5. American National Standards Institute and American Society for Testing and Materials measurement procedures are in place for $\mathrm{Pu} / \mathrm{Am}$ assay using calorimetry and gamma-ray isotopics. ${ }^{2,3}$

6. The calorimeter measurement is slow compared to neutron counting. Typical assay times are 4 to 8 hours for calorimetry, and 1 hour for the associated high-resolution gamma-ray spectroscopy analysis. 


\section{SPECIFIC POWERS FOR MINOR ACTINIDES}

Table I summarizes the specific power in milliwatts per gram for some minor actinides and special nuclear materials. The same information is portrayed in Figure 3 as a graph of relative specific powers. The specific powers range from high values such as 324 milliwatts per gram for tritium to low values such as $0.0018 \mathrm{~mW} / \mathrm{g}$ for HEU that contains $1 \% \mathrm{U}-234$. Actinides such as Am-241 and Am-243 have specific powers that make them easy to measure by calorimetry. For Np-237, the specific power is $0.0207 \mathrm{~mW} / \mathrm{g}$. A sample of Np-237 would have 100 times less the specific power of a Pu-239 sample with a similar mass. Thus the relative accuracy of a calorimetric assay of Np-237 would be less.

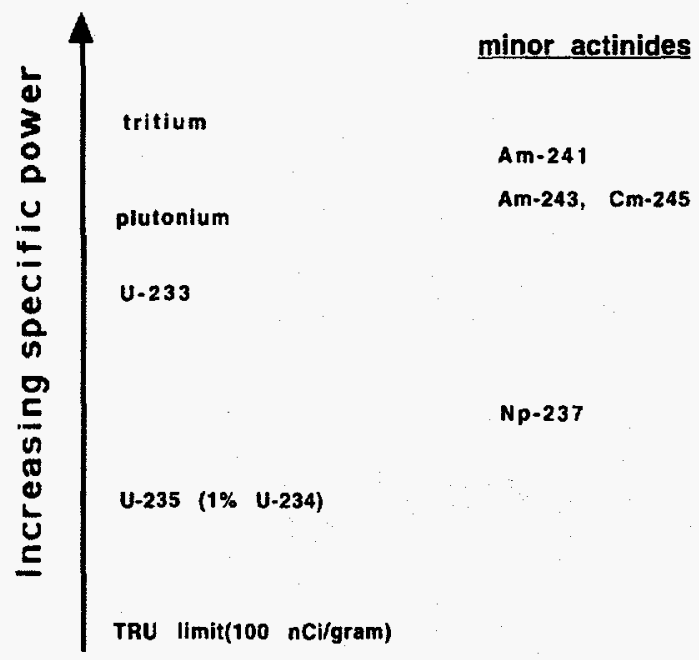

Figure 3. Relative specific powers for some special nuclear materials and minor actinides.

\begin{tabular}{|c|c|c|c|}
\hline \multicolumn{4}{|c|}{$\begin{array}{l}\text { Table I. The Specific Power, in Milliwatts Per Gram, for a } \\
\text { Number of Minor Actinides and Special Nuclear } \\
\text { Materials }\end{array}$} \\
\hline \multicolumn{2}{|c|}{ Minor Actinides } & \multicolumn{2}{|c|}{ SNM } \\
\hline Isotope & $\begin{array}{c}\begin{array}{c}\text { Specific Power } \\
(\mathrm{mW} / \mathrm{g})\end{array} \\
\end{array}$ & Isotope & $\begin{array}{c}\begin{array}{c}\text { Specific Power } \\
(\mathrm{mW} / \mathrm{g}\end{array} \\
\end{array}$ \\
\hline${ }^{232} \mathrm{U}$ & 689.7 & tritium & 324 \\
\hline${ }^{232} \mathrm{U}^{*}$ & $5.3 \times 10^{3}$ & ${ }^{238} \mathrm{Pu}$ & 567.6 \\
\hline${ }^{233} \mathrm{U}$ & 0.2808 & ${ }^{239} \mathrm{Pu}$ & 1.929 \\
\hline${ }^{234} \mathrm{U}$ & 0.1803 & ${ }^{240} \mathrm{Pu}$ & 7.0824 \\
\hline${ }^{241} \mathrm{Am}$ & 114.4 & ${ }^{24 !} \mathrm{Pu}$ & 3.412 \\
\hline${ }^{243} \mathrm{Am}$ & 6.436 & ${ }^{242} \mathrm{Pu}$ & 0.1159 \\
\hline${ }^{245} \mathrm{Cm}$ & 5.698 & ${ }^{23} 5 \mathrm{U}$ & $5.996 \mathrm{E}-05$ \\
\hline${ }^{237} \mathrm{~Np}$ & 0.02071 & ${ }^{238} \mathrm{U}$ & 8.51E-06 \\
\hline
\end{tabular}




\section{ISOTOPIC MIXTURES}

There is considerable experience with the use of calorimetry and high-resolution gammaray spectroscopy to nondestructively determine the isotopic compositions and masses of mixtures of SNM. Mixtures that have been determined in this way include the following:

1. Am-241/Pu

2. Isotopically heterogeneous $\mathrm{Am}-241 / \mathrm{Pu}$

3. U/Pu (mixed oxide)

4. $(\mathrm{Pu} / \mathrm{Am}-241) / \mathrm{Np}-239$

However, for some mixtures of SNM and minor actinides, the use of calorimetry and high-resolution gamma-ray spectroscopy has not yet been studied, and further evaluation is needed. An example is given in Table II, below, which summarizes the heat output from a hypothetical sample containing $1 \mathrm{~kg}$ of $\mathrm{Np}-237$ and $10 \mathrm{~g}$ of $\mathrm{Pu}$ of either weapons-grade or reactor-grade isotopic composition. In this example, the plutonium content is about $1 \%$ of the total nuclear material content. However, the plutonium may yield as much or more heat as the neptunium. Thus it is important to investigate the accuracy with which high-resolution gamma-ray spectroscopy can determine the Pu/Np ratio. At Los Alamos, we have begun to make calorimeter and gamma-ray isotopic measurements of Np-237/Np-239/Am-243 samples.

\begin{tabular}{|l|l|}
\hline Table II. & $\begin{array}{l}\text { Heat Output Calculation for a Hypothetical } \\
\text { Sample Containing } 1 \mathrm{~kg} \text { of } \mathrm{Np}-237 \text { and } 10 \mathrm{~g} \text { of } \\
\text { Plutonium of Either Weapons-Grade or Reactor- } \\
\text { Grade Isotopic Composition. }\end{array}$ \\
\hline \hline Case 1: & $\begin{array}{l}{ }^{237} \mathrm{~Np} \text { and } 1 \% \text { by weight reactor grade Pu }\left(25 \%{ }^{240} \mathrm{Pu}\right) \\
\text { Total power for } 1000 \mathrm{~g}{ }^{237} \mathrm{~Np}=21 \mathrm{~mW} \\
\text { Total power for } 10 \mathrm{~g} \mathrm{Pu}=135 \mathrm{~mW} \\
\text { \% of power due to }{ }^{237} \mathrm{~Np}=13 \%\end{array}$ \\
\hline Case 2: & $\begin{array}{l}{ }^{237} \mathrm{~Np} \text { and } 1 \% \text { by weight weapons grade } \mathrm{Pu}\left(6 \%{ }^{240} \mathrm{Pu}\right) \\
\text { Total power for } 1000 \mathrm{~g}{ }^{237} \mathrm{~Np}=21 \mathrm{~mW} \\
\text { Total power for } 10 \mathrm{~g} \mathrm{Pu}=25 \mathrm{~mW} \\
\% \text { of power due to }{ }^{237} \mathrm{~Np}=46 \%\end{array}$ \\
\hline
\end{tabular}

\section{v. CONCLUSIONS}

Calorimetry and high-resolution gamma-ray isotopic analysis can be used for the assay of minor actinides by adapting the methodology developed for Pu/Am-241, as described in ANSI N15.22 and ASTM C 1030-89. We are beginning to carry out calorimetric measurements of minor actinides for test and evaluation of these methodologies. Mixtures of SNM and minor actinides will require further evaluation, and we are beginning to study the technical requirements for assaying such mixtures. In some cases we will develop new methodologies that involve a mixture of destructive analysis techniques and NDA techniques such as calorimetry, gamma-ray isotopics, active neutron counting, or passive neutron counting. 


\section{REFERENCES}

1. C. R. Rudy, L. J. Satkowiak, W. W. Rodenburg, and J. A. McDaniel, "Calorimetric/Gamma-Ray Assay of High Enriched Uranium," Nucl. Mater. Manage. XXII, 1118-1123 (1993).

2. American National Standards Institute standard for nuclear materials ANSI 15.22 -1987, "Plutonium Bearing Solids - Calibration Techniques for Calorimetric Assay," approved January 1987.

3. American Society for Testing and Materials standard test method ASTM C 1030 - 1989, "Standard Test Method for Determination of Plutonium Isotopic Composition by GammaRay Spectroscopy." 


\title{
ENVIRONMENTAL ANALYSIS OF TRANSURANIC NUCLIDES
}

\author{
P. H. Hemberger, D. W. Efurd, D. J. Rokop \\ Chemical Sciences and Technology Division \\ Los Alamos National Laboratory
}

This presentation discusses the issues associated with, and presents capabilities of, detection of transuranic nuclides in environmental matrices. This discussion will consider (1) the existing background concentration of ${ }^{241} \mathrm{Am}$ and ${ }^{237} \mathrm{~Np}$ in the environment, (2) current detection technologies, and (3) present and future needs and issues.

\section{BACKGROUND CONCENTRATIONS}

Neptunium-237 in the environment can be accounted for primarily by global fallout. Environmental measurements of ${ }^{237} \mathrm{~Np}$ in soil samples collected in the USA using thermal ionization mass spectrometry show concentrations of $\sim(1-2) \times 10^{8}$ atoms $/ \mathrm{g}$, with a ${ }^{237} \mathrm{~Np} /{ }^{239} \mathrm{Pu}$ ratio of $0 \pm 0.2$. Based on this average, an estimated $3000 \mathrm{~kg}$ of ${ }^{237} \mathrm{~Np}$ has been released to the environment. However, the ${ }^{237} \mathrm{~Np}$ concentration from soil samples collected around nuclear power plants has been measured at about $3 \times 10^{11}$ atoms/g. Americium-241 is present in the environment via a number of pathways, including grow-in from ${ }^{241} \mathrm{Pu}$ and from commercial sources. In 1982, the amount of ${ }^{241} \mathrm{Am}$ from ${ }^{241} \mathrm{Pu}$ in the environment was estimated at about $25 \%$ of the ${ }^{239,240} \mathrm{Pu}$ activity and is expected to increase to about $40 \%$. One estimate puts the ${ }^{241} \mathrm{Am}$ concentration in soil at about $2 \times 10^{6}$ atoms $/ \mathrm{g}$ for two locations in the USA. Around nuclear facilities, the dispersion of ${ }^{241} \mathrm{Am}$ can range from $3.5 \times 10^{9}$ atoms/g to about $2 \times 10^{14}$ atoms/g. It is generally agreed that the most of the distribution of ${ }^{237} \mathrm{~Np}$ and ${ }^{241} \mathrm{Am}$ in soil lies within the first few centimeters. One estimate places $80-90 \%$ of these nuclides in the first $10 \mathrm{~cm}$ of surface soil. In surface soils, the migration rates of ${ }^{237} \mathrm{~Np}$, ${ }^{239.240} \mathrm{Pu}$, and ${ }^{241} \mathrm{Am}$ are thought to be similar although their migration behavior obviously depends strongly on the physical and chemical properties of the soil. In sediments and aquatic samples, it has been shown that ${ }^{237} \mathrm{~Np}$ is more mobile (and soluble) than plutonium. When assessing ${ }^{241} \mathrm{Am}$ profiles, the ingrowth from ${ }^{241} \mathrm{Pu}$ must be considered a source of this nuclide.

\section{CURRENT DETECTION TECHNOLOGIES}

Mass spectrometry and radiochemical diagnostics are the principal detection methods for environmental concentrations of ${ }^{237} \mathrm{~Np}$ and ${ }^{241} \mathrm{Am}$. Thermal ionization mass spectrometry is probably the most sensitive-and expensive-method. Detection limits approach levels of $10^{8}$ atoms (tens of femtograms) for either nuclide. These limits can potentially be lowered using resin bead loading techniques. Detection limits are about a thousand-fold higher using inductively coupled plasma mass spectrometry. A method based on chemical separations and alpha spectrometry for a variety of transuranium elements, including ${ }^{237} \mathrm{~Np}$ and ${ }^{241} \mathrm{Am}$, has been reported with detection limits (per nuclide) of $10 \mathrm{fCi} / \mathrm{sample}$. This corresponds to about 3 femtograms for ${ }^{241} \mathrm{Am}$, and 14 picograms for ${ }^{237} \mathrm{~Np}$. Another report describes a sequential separation scheme for $\mathrm{Np}, \mathrm{Pu}, \mathrm{Am}$, and $\mathrm{Cm}$ followed by alpha spectrometry using radionuclide tracers (e.g. ${ }^{239} \mathrm{~Np},{ }^{243} \mathrm{Am}$ ), with detection limits of $30 \mathrm{fCi}$ per sample (10 g soil; $25 \mathrm{~g}$ 
dry meat; $50 \mathrm{~g}$ bone ash). Neutron activation has been used to study the uptake of ${ }^{237} \mathrm{~Np}$ in marine plants and animals. Here neutron irradiation of ${ }^{237} \mathrm{~Np}$ produces ${ }^{238} \mathrm{~Np}$, which is detected by $\mathrm{x}$-ray spectrometry using a $\mathrm{Ge}(\mathrm{Li})$ detector. Detection limits are about $0.5 \mathrm{pg}$. Separation and preconcentration steps were used for these analyses. In short, thermal ionization mass spectrometry using isotope dilution techniques is perhaps the most sensitive and accurate method for determination of environmental levels of ${ }^{237} \mathrm{~Np}$ and ${ }^{241} \mathrm{Am}$. Neutron activation analysis is the second most sensitive technique for ${ }^{237} \mathrm{~Np}$, while alpha spectrometry is competitive with mass spectrometry for ${ }^{241} \mathrm{Am}$.

\section{NEEDS AND ISSUES}

It should be apparent from the above paragraph that low-level detection methods are complex and.time consuming, and require expensive instrumentation. Faster and lessexpensive detection methodologies would be of benefit, especially since accurate assessment of data would also require plutonium analysis in the sample. Analytical methods that reduce the need for chemical separations would likely lower cost and time of analysis, even if the instrumentation itself were expensive. An example of such a method is resonance ionization mass spectrometry. While nondestructive analysis methods and environmental measurements tackle opposite extremes of the concentration scale, there are two key areas for development that would serve both forms of analysis. Although separation procedures for both $\mathrm{Np}$ and Am are in use, improvements in sample recoveries and speed are needed. There is also a critical need for certified standards for both low-level mass spectrometry and radiochemical methods (e.g., $a^{236} \mathrm{~Np}$ standard would be invaluable for mass spectrometry).

Summary of Presented Data

\begin{tabular}{|c|c|c|c|c|}
\hline Nuclide & $\begin{array}{c}\text { "Background" } \\
\text { Concentration }\end{array}$ & $\begin{array}{c}\text { High Local } \\
\text { Concentration }\end{array}$ & $\begin{array}{c}\text { 1st Analytical } \\
\text { Method }\end{array}$ & $\begin{array}{c}\text { 2nd Analytical } \\
\text { Method }\end{array}$ \\
\hline $\mathrm{Np}-237$ & $2 \times 10^{8}$ & $3 \times 10^{11}$ & TIMS & NAA \\
\hline Am-241 & $2 \times 10^{6}$ & $2 \times 10^{14}$ & TIMS & Alpha Spec. \\
\hline
\end{tabular}

Environmental concentration values in atoms per gram of soil.

TIMS = Thermal ionization mass spectrometry.

NAA $=$ Neutron activation analysis. 